\title{
The Pre-Republic Period of the Turkish Automotive Industry: Design and Production
}

\author{
Fuat Ali Paker1, Cem Alppay¹, Begüm Sertyeşilışık² \\ ${ }^{1}$ Industrial Design Department of Istanbul Technical University, Istanbul, Turkey \\ ${ }^{2}$ Architecture Department of Istanbul Technical University, Istanbul, Turkey \\ Email: pakerf@itu.edu.tr
}

How to cite this paper: Paker, F. A., Alppay, C., \& Sertyeşilışık, B. (2018). The Pre-Republic Period of the Turkish Automotive Industry: Design and Production. Art and Design Review, 6, 185-194. https://doi.org/10.4236/adr.2018.64018

Received: August 31, 2018

Accepted: November 2, 2018

Published: November 5, 2018

Copyright () 2018 by authors and Scientific Research Publishing Inc. This work is licensed under the Creative Commons Attribution International License (CC BY 4.0).

http://creativecommons.org/licenses/by/4.0/

cC) (i) Open Access

\begin{abstract}
This study was compiled by scientific research publication sheds light on the historical development of the Turkish automotive industry has been compiled for the period of conservation of the original value. The decline in industrial development in the last century of the Ottomans is directly proportional to the progress of Europe in the last century. This decline in the country's pre-republican industry has surpassed to the rise with the subsequent European customs union agreements. This rise, which is focused on the defense industry in the pre-republican automotive sector, has resulted in successive private sector expansion with regional agreements. Turkey's automotive industry rise with the European customs union agreement, and alternative regional agreements, showed stronger growth. The time of establishment and expansion of the world automotive industry coincides with the last days of the pre-republican Ottoman Empire in our country. Therefore, both the development of this sector, as well as information related to transportation in this industry has been experiencing difficulties. Ottoman archives transcription studies state institute of statistics by ten years period the last period statistically. But it's quite old Ottoman archives of Latin translations in the compilation of this data with their letter pretty much will take time.
\end{abstract}

\section{Keywords}

Turkish Automotive Industry, Historical Development of Industry, Vehicle Design

\section{Introduction}

Shedding light on the historical development of the Turkish automotive industry (pre-installation of the production and design) in this study is discussed in three sections. With the current state of the industry in the first episode illuminates 
the Ottoman period related to fieldwork. The second Section shows the global vehicle industry spread during the arrival of the first Turkish automobile at the time, and the Organization of the industry-related share one's knowledge and documents. Finally the present automotive industry and vehicle design compile to work in Turkey.

\section{Historical Development of the Turkish Automotive Industry}

\subsection{Pre-Republic Period of the Industrial Development}

The late 18th century, the era of the establishment and diffusion of the world automotive industry, the developments in our country have played an important role in the late restructuring of this industry. Therefore, the development of the automotive industry in the world coincided the last days of the Ottoman Empire, led to this work period-related archival research. In our country, published fieldwork examined vehicle industry: after the period of the Republic or the historical development of the global automotive trade includes research. Turkey Statistics Institution (TUIK) which is founded in February 26, 1926 and in the year 1962 began studying; has been regularly preparing works for various scientists about the pre-Republic period for the last twenty years. Freed of the Latin letters from Ottoman language translations of industrial development of the Ottoman archives for statistics seems to be limited to this day learn that contains (Çiftçi \& Seymen, 2011). Translated to the Latin alphabet transcription statistics work from the Ottoman language in late Ottoman industry count that contains the current state of related studies period (Ökçün, 1997; Pamuk, 2004; Pamuk, 2006; Findıkoğlu, 1940; Önsoy, 1988; Topuz, 1993). The most powerful force in the world two centuries are considered when looking at the history of the Ottoman Empire only to talk about the agricultural society does not seem possible. Therefore, the period examined, the Commerce and industry, the agricultural sector is important at least as much as economic life can be observed (Çiftçi \& Seymen, 2011; Ökçün, 1997; Topuz, 1993). Tradesmen who have a say in the city life, take place in the Ottoman Empire together with their high economic power position. Tradesmen and artisans, as well as workers in the Ottoman cities, are considered to be even more valuable than the western economies (Findikoğlu, 1940; Önsoy, 1988). Period related researcher Pamuk (2004), based on more than 5000 transcription report, the values given by: 16th century, the wages earned by the employee in Europe, $40 \%$ of free Ottoman industrial level have survived until today (Pamuk, 2004). Although this rate seems to be a high labor cost, it shows that even at the beginning of the twentieth century in Istanbul, skilled workers' wages can only catch $60 \%$ of the UK (Pamuk, 2006). The Ottomans, far from technological developments in the second half of the 18th century, have also moved away from the industrialization brought by this progress. It may seem a single trade the automotive industry; chemical, glass, metal, textile, defense industry, insurance, finance, includes the development of the sector 
and many others. In the last period of the Ottoman period the regular regression in the industry paralleled with the regular increase in the European industry (Medina, 1969): Europe's presence in world industrial production was at 39.5\% in 1830 , reaching $79 \%$ in 1880 (Çiftçi \& Seymen, 2011), by 1913, it had risen to $92 \%$ (Clingingsmith \& Williamson, 2008). Thus, in 1868, the number of fabric looms which were at the level of 2750 in Istanbul 30 - 40 years ago reached 25 30 looms (Sarc, 1940). In Tirnova, the number of weaving looms, which was 2000 before 1800, declined to 200 in 1830. In the Ottoman Empire, before 1810, this ratio increased from 40 weaving looms to 600 (Findıkoğlu, 1940). It is possible to reach the result that the Ottoman industrialist who has a deep-rooted tradition is in the scale of the world (Çiftçi \& Seymen, 2011; Topuz, 1993). The factories that were established for the production of textile and textile machinery in Europe have been turned into automotive manufacturing due to the vehicle replenishment needs arising from world wars.

\subsection{Pre-Republic Period of the Automotive Industry}

Henry Ford is the first serial car manufacturer with an important position in the automotive industry in Turkey and founded his factory in Detroit at the age of 40, in June 16, 1903 (Kerwin, 2003). He has set up a \$28,000 plant with 12 investors, including John and Horace Dodge, with a 25\% stake (Meyer, 1981). The first serial manufacturing, mass product designs and implements the principles of Ford Company (Taylor, 2003), in those years, automobile, trucks, tractors, and aircraft manufacturing has realized many class vehicles until production (Meyer, 1981).

The Ford Company established an assembly plant in Istanbul's Tophane-Turkey (Figure 1) free zone on February 2, 1929 with 25,617 square meters of land for 25 years, with the right to use trucks to export to the Russian government (Odman, 2011). The world economic crisis, which began a year after its foundation, severely affected Ford's assembly plant three years later and greatly reduced manufacturing productivity (Odman, 2011; Okur \& Serdaroğlu, 1994). Turkey's first "Free Zone" experience, which began in Tophane-Turkey (Figure 1) Ford truck assembly bonded warehouses, was realized with the duty-free import of vehicle parts (Odman, 2011). Therefore, the Istanbul Ford Assembly factory, which has been in agreement with the state for 25 years, was closed in 1944. The Ankara chamber of commerce president in 1945 winner VehbiKoç (Koç Trade Inc.) was in Ford Company's general representative of Turkey (Okur \& Serdaroğlu, 1994). Turkey has tried to stay away from the Second World War, with the help of the US Marshall, Turkey begun buying trucks, agricultural machines and tractors (Bedir, 1999; Yaşar, 2013).

Vehicles used in the Second World War the importance of the defense industry for the installation of the Turkish Government who noticed Turk Willy (Figure 2) has led the company (1954). The assembly production of military road vehicles (jeeps and trucks) has been put into effect through the automotive company (Bedir, 1999; Yaşar, 2013). Istanbul Ford Assembly Factory, which 


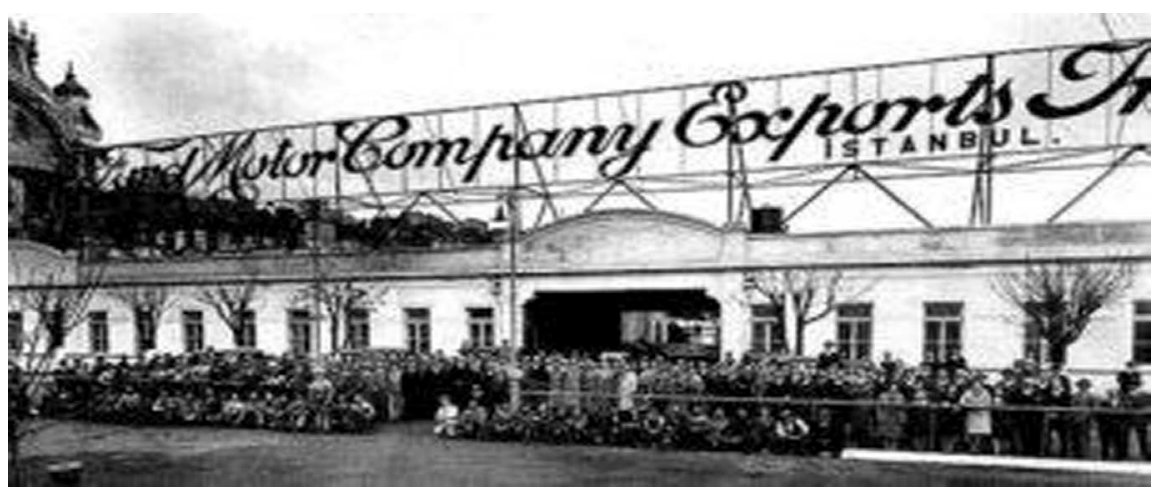

Figure 1. The Russia was established for the export of the first assembly plant (Odman, 2011).

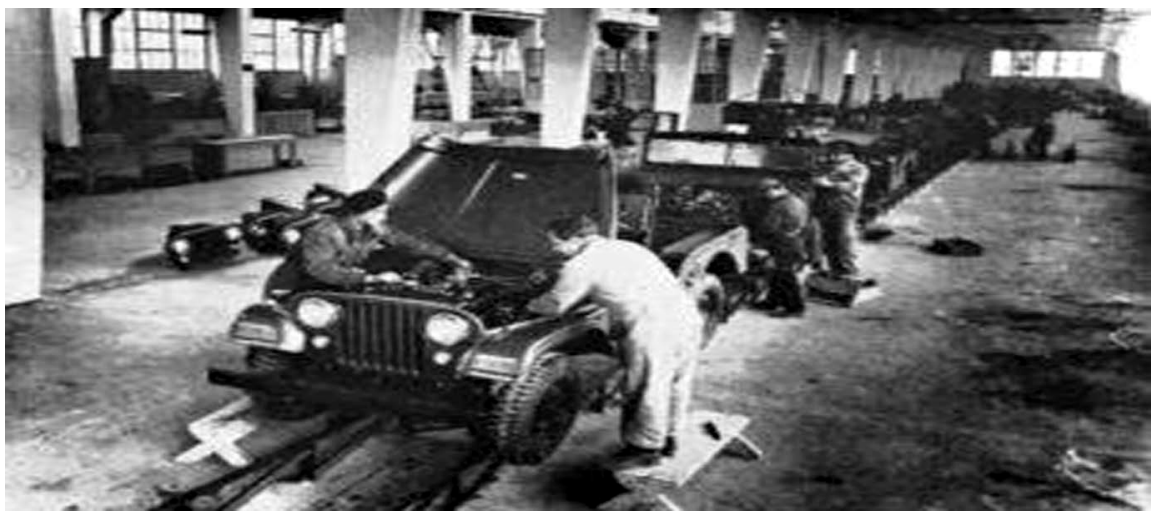

Figure 2. First Turkish automotive factories (Willy Jeep) in Tuzla, Turkey (Okur \& Serdaroğlu, 1994).

closed in 1944, was established with the partnership of Koç Company and took its place in the private sector as Ford Otosan (1958) in İstanbul region. Çiftçiler Inc. started to install the vehicle with the bus body manufacturing factory that it established in 1963 and at the same time the Turkish Askam Inc. firm began to manufacture the vehicle (Bedir, 2002; Tonus, 2007). In the three years that followed: the Koç Inc. in partnership with Italian Fiat license company Tofaş Inc. (Turkey Automobile Factory Corporation) automotive assembly plant, the Oyak Inc. (Military Assistance Corporation) in partnership with French Renault licenses has started mass production of automobile Factories Oyak Renault Inc. started assembling vehicles (Bedir, 2002; Tonus, 2007). 1960 in the second half of our country; Otomarsan Inc. (Mercedes's licence), Otoyol Inc. (Iveco's licence), Karsan Inc. (Peugeot's licence), BMC Inc. (British Motor Company), quasi to automotive company started assembling vehicles (Bedir, 2002; Tonus, 2007). 1970 world petrol crisis in 1980 created the exchange until the downturn, so deeply influenced by the automotive sector (Tonus, 2007). After the world oil crisis, the main industrialization-dependent automobile sector has been revived with a variety of products. In the 1990s, the government implemented special tax reductions with the aim of improving the state automotive assembly industry. In 1995, a customs union agreement was reached with Europe and commercial 
taxes were exempted. In 2000 the German Opel firm established the assembly plant in our country (Tonus, 2007). In 1994, Toyota established Honda and Hyundai automotive assembly factories in our country The European Customs Union Agreement (Table 1) shows significant diffraction for the automotive assembly industry and the country's economy in our country (Çakmak, 2017). Nowadays, the country's automotive industry a total of 12 main brands dependent, 6 is independent, and totally there are 18 automotive factories.

The last period of the Ottoman Empire, it's time for the installation and development of the world automotive industry. Nomadic society Turkish public from the automotive industry a culture so far is a matter to be explored in itself remain. There is little written history related research in this period: state administration (II. Abdülhamid) of traditional conservative attitude, or women, is used for transporting weapons and cargo cart, force of expression does not shows a preference for (saddle horse preference) men (Çolak, 2003; Türkmen, 2003; Șener, 2007). During this period the carriage from Europe, is the model

Table 1. Historical development of the Turkish automotive industry.

\begin{tabular}{|c|c|c|c|c|c|}
\hline \multicolumn{6}{|c|}{ The First Automotive Activities (The Ottoman Period) } \\
\hline \multicolumn{6}{|c|}{ The first automobile date of dispatch to II. Abdülhamid. } \\
\hline \multicolumn{6}{|c|}{ The first official automobile imports (Züheyrzâde Ahmet Pasha and Stavrolu) } \\
\hline \multicolumn{6}{|c|}{ Mahmut Şevket Pasha's automobile in the assassination. } \\
\hline \multicolumn{6}{|c|}{ First automotive road and traffic regulations in the Ottoman. } \\
\hline \multicolumn{6}{|c|}{ The First Automotive Industry Companies (Pre-Republic Period) } \\
\hline Automotive Company Name & $\begin{array}{l}\text { Foundation } \\
\text { Year }\end{array}$ & $\begin{array}{l}\text { Factor }) \\
\quad(\text { per }\end{array}$ & $\begin{array}{l}\text { Capacity } \\
\text { year) }\end{array}$ & $\begin{array}{l}\text { Company Capital } \\
\text { (mil. TL) }\end{array}$ & $\begin{array}{c}\text { Foreign } \\
\text { Capital (\%) }\end{array}$ \\
\hline $\begin{array}{l}\text { Ottoman Transport Vehicles } \\
\text { Inc. Company }\end{array}$ & 1916 & - & $\begin{array}{l}\text { Truck } \\
\text { Jeep }\end{array}$ & - & 0 \\
\hline $\begin{array}{l}\text { Ford Motor Export Istanbul } \\
\text { Inc. Company }\end{array}$ & 19271944 & - & $\begin{array}{l}\text { Truck } \\
\text { Car }\end{array}$ & $\$ 0.018$ & 100 \\
\hline \multirow{3}{*}{$\begin{array}{l}\text { Turk Willys Overland Inc. } \\
\text { Company }\end{array}$} & & 5800 & Truck & & \\
\hline & 1954 & 7500 & Jeep & - & 25 \\
\hline & & 1000 & Bus & & \\
\hline $\begin{array}{l}\text { Turkish Automotive Industry } \\
\text { (TOE) Inc. Company }\end{array}$ & 1955 & 400 & Truck & 20 & 10 \\
\hline \multicolumn{6}{|c|}{ The European Customs Union Reference, 1959 (Republic Period: 1971 EU Agreement) } \\
\hline Ford Otosan Inc. Co. & 1959 & $\begin{array}{l}200 \\
400\end{array}$ & $\begin{array}{l}\text { Truck } \\
\text { Minibus }\end{array}$ & 1 & License \\
\hline Çiftciler Inc. Co. & 1959 & 1800 & Truck & 0.25 & License \\
\hline Turk Askam Inc. Co & 1964 & 6000 & Truck & 20 & License \\
\hline Istanbul Bus Carocer Inc. Co & 1963 & 320 & Bus & 5.4 & License \\
\hline Genoto Inc. Co. & 1963 & 3000 & Truck & 5 & License \\
\hline
\end{tabular}


used in the tumbrel construction these days is concentrated in the Marmara region of the automotive industry. The invention of the automotive in the world, the last years of the Ottoman Empire in our country or spread, due to coincide with the relevant written records is limited due to the world wars and language change. The development of automobile in our country dates back to the period of (1876-1909) II. Abdulhamid (Muhit, 2012). Council of state member, Basra deputy Züheyrzâde Ahmet Pasha and district governor Stavrolu the first automobile "auto-car: self-propelled" imports to our land (Muhit, 2012). In 1888, Hotchkis and Mercedes brand cars were sent to II. Abdülhamit as a gift, and they are included in the period records that they have never used (Karakişla, 2002). With the 1908 Constitutional Constitution, the automobile began to spread in Istanbul, but MahmutŞevket Pasha's assassination in the automobile (June 11, 1913) reduced the interest of state officials on the road (Türkmen, 2003). During this period, palace's women and patients first benefited from the automobile on the other hand men did not drive unless they were ill. In the early years of the Constitution, the army was close to a novelty like automobile. During this period, military leaders predicted the importance of using motor vehicles in wars. The Ottoman Transport Vehicles Company was established in 1916 to import military trucks (Figure 3) and this company has made an important place in the development of the automotive industry in the country (Şener, 2007).

The Ottoman last period, the automotive parts manufacturing industry developed in the area of Saraçhane-Istanbul square (Şener, 2007). In the period of Mithat Pasha, related technical schools have been active. The newly opened industrial vocational schools established a factory for the application (Şener, 2007). Successful graduates in these schools have been trained in Europe in order to be able to transfer technology and science to the country at that time, thus contributing significantly to the development of the automotive industry (Ekrem, 1898). The need for industrial vocational schools has emerged in the Tanzimat reform era for the first time (Şener, 2007). Especially in the first constitutional period after the II. Abdulhamid, term reformatory household's start-up industrial school (Şener, 2007). However, 1894 until students can be considered substantial increase of annual expenditures reduction (Ekrem, 1898). During the period

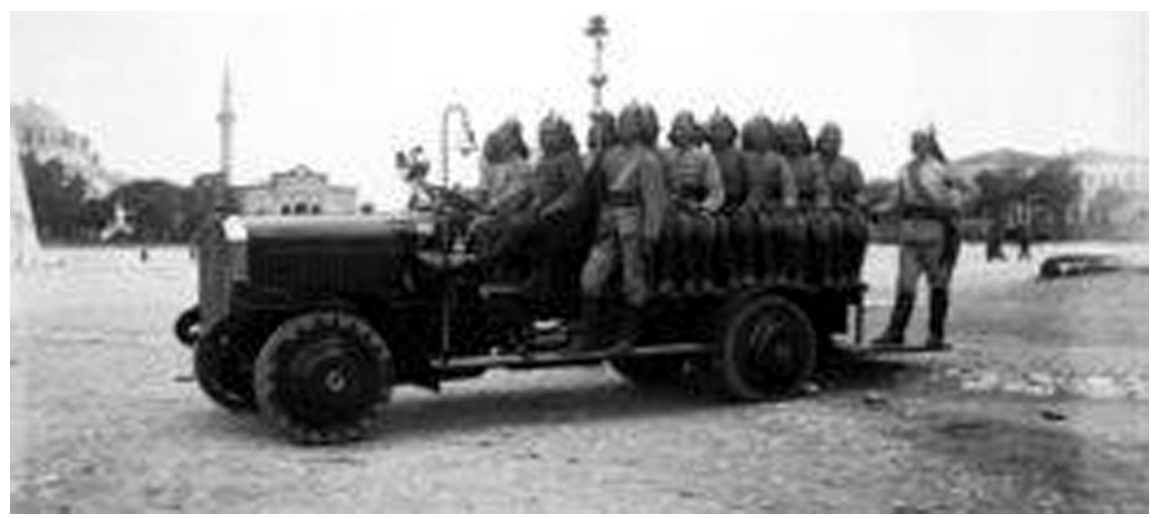

Figure 3. The first Ford defences truck in Ottoman (Şener, 2007). 
of Mithat Pasha (1894), these schools became widespread and led their education life in their own buildings (Şener, 2007). Reformatory households, this term has gained real industrial school ID, industry training has increased the numbers of these schools (Şener, 2007). Brought up to the First World War, the need for technical staff in Istanbul were met this industrial school graduates and the proliferation of great importance for the development of technical vocational school (Ekrem, 1898). Graduates specialize in various European countries, has provided students the opportunity to better upbringing. But in this period of economic crisis, the newly opened industry schools could not meet the expected quality of staff (Ekrem, 1898).

\section{Historical Development of the Turkish Automotive Design}

The establishment of the Republic in the automotive industry has with semi-finished parts, service, or import substitution. The early history of the Republic at the time up to 1955 years of automotive parts manufacturing industry has experienced significant improvements, but an independent attempt has not been involved in the Turkish Automotive global brand. OYAK established, Turkish Automotive Industry Inc. (TOE) in 1955 and interviewed with Volvo for the first Turkish car production. But it was agreed with British Triumph Company for the design and manufacture of this vehicle called "Zafer". In fact, the first Turkish automobile design and manufacturing enterprise has been in the project phase due to various reasons. President Cemal Gürsel, who saw the importance of this industry as an input to the developed country's economy, decided to design and manufacture the first independent Turkish automobile in the state. 1,500,000 TL budget, with a team of 20 people started this project in Eskişehir-Turkey train factory of TCDD on October 29, 1961 at a four month period of time (Engin, 1994). The "Devrim", which was the first domestic automobile to date in the history of the Turkish automotive industry, is a vehicle that does not have factory installation and mass production investments, but rather remains a conceptual prototype stage. In this project the project manager was EminBozoğlu, design group members were (first Turkish automotive designers): NurettinErguvan, ErcanTürer, Kemal Elagöz (Engin, 1994). The lower groups of the project were: project management, motor chassis, design, body parts, suspension and braking, electrical components, castings and formed sections, such as cost accounting (Sağın, 1985). The third domestic automobile experiment that went into the history of Turkish automotive industry (1966), within the scope of the Ford Otosan company (produced until 1984) “Anadol” brand model vehicles (Emiroğlu, 2017). The vehicle design was carried out by the British Reliant company and the designer was Tom Karen (Emiroğlu, 2017). The design and development of this vehicle, which is carried out abroad, is not accepted because of the locality of its manufacture. The Ford Anadol model, which is the third domestic automobile in the history of Turkish automotive industry, has a very low proportion of product development project group and used parts. The automotive designers Jahn Nahum and EralpNoyan were involved in the develop- 
ment of the next version of the Anadol model vehicle, which was developed under the Ford brand. The fourth domestic automobile case the history of the Turkish automotive industry was named as "Proton", which was produced by Jetpa Motor Inc. (Koyuncu, 2015). In 1999, "Imza", that is the name of the car, was introduced and developed with a strategic approach supported by Malaysian government's domestic automobile enterprise (Koyuncu, 2015). The car was run with a local development team: Osman Boyd in project management, Sinan Tanju in factory manufacturing management, AliPaker in design management and Üzeyir Pala in documentation management. Unlike the others, the molds of the "Signature" brand car and the factory investment in the Siirt region, together with the production of 5 pre-series cars manufactured. 2017 as of today, at the premises of the TUBITAK (Gebze-Turkey), there is one hundred percent domestic automobile projects (Table 2). As with the first domestic automobile project, the investment in the factory set-up or serial manufacturing and assembly of the resulting product maintains its ambiguity. Table 2 lists the new brand initiatives of post-republic national automotive industry.

\section{Findings and Discussion}

With the decline of the Ottoman industry in the 18th century, the rapid progress of the European industry in this century has been directly proportional. It seems that the Ottomans are late, in terms of industrial investments or regional agreements, in this period, when technology-focused inventions made in automotive and support industries have increased. Having established railway systems by making imports, the Ottomans could not obtain sufficient results even if they opened schools for industrial development. Economic conditions in the post-World Wars have brought industrial development to a halt in our country. The transition to the republican regime did not change this end. This decline in the country's industry has gained momentum in the framework of regional (European Customs Union) agreements. This rise, which is focused on the automotive sector and the defenses industry, has spread in succession as a private sector under regional agreements. Therefore, the result is that, the growth environment of the parent company is fed from regional markets, which are formed from global areas instead of local ones. The automotive assembly industry, which was

Table 2. Historical development of the Turkish automotive design.

\begin{tabular}{|c|c|c|c|c|c|c|}
\hline \multicolumn{7}{|c|}{ The Turkish Automotive Industry Examples of Local Car Design } \\
\hline CarDesign Brand Owner & $\begin{array}{l}\text { Design } \\
\text { Name }\end{array}$ & $\begin{array}{l}\text { Design } \\
\text { Date }\end{array}$ & $\begin{array}{l}\text { Design } \\
\text { Place }\end{array}$ & $\begin{array}{l}\text { Design } \\
\text { Firm }\end{array}$ & $\begin{array}{c}\text { Investment } \\
\text { Amount (TL) }\end{array}$ & Production \\
\hline Turk Automotive Industries Inc. Comp. (TOE) & Tayfun & 1958 & British & Triumph & 5000 & 1 \\
\hline Turkey President Cemal Gürsel & Devrim & 1961 & Turkey & TCDD & 1500 & 3 \\
\hline Ford Otosan Inc. Comp. & Anadol & 1966 & British & Reliant & - & Serial \\
\hline Jetpa Motor Inc. Comp. & Imza & 1999 & Turkey & Jetpa & $5,000,000$ & 5 \\
\hline Turkey President Recep TayipErdoğan & - & 2017 & Turkey & TUBITAK & - & - \\
\hline
\end{tabular}


formed in the last days of the Ottoman Empire, constitutes the main economic indicators of the countries with its production today. Today, the automotive assembly industry, which is rapidly developing at high speed, is continuing under global agreements in different regions with mass production and high technology development. The choice to take place on one side of the balance depends on the countries strategies, as well as global automotive brands. By the year 2017, the first mass production of the Turkish automobile is attempting to be established at the governmental level, and the investments, agreements or business models required for industrial and technological development remains uncertain. Table 1 shows the developments in the pre-republic of the country's automotive industry. The establishment of the national automotive industry firm in Table 2 has been concentrated in the 1960s because the era of international vehicle companies in the global market is also in this period.

In the same period, after the world wars, the new global automobile companies and their history are as follows: Jaguar 1945, Porsche 1947, Ferrari 1947, Honda 1964, Lada 1966, Dacia 1966, Hyundai 1967, Daewoo 1967, Proton 1983, etc.

In this period, the state-supported automobile factory installations that the government can take as an example are; Romania-Dacia, Russia-Lada, South Korea-Daewoo, Malaysia-Proton etc. There are few publications in our country regarding the historical occurrences of industries that have a decisive role in national and international economies, and this affects the development of those industries In this study, it is suggested to increase the researches about the formation, development or situation analysis of the automotive industry, space and aircraft industry, railway systems, electronics and similar industries. The aforementioned industrial researches provide a variety of field use and benefits from interdisciplinary scientific approaches to technological studies.

\section{Conflicts of Interest}

The authors declare no conflicts of interest regarding the publication of this paper.

\section{References}

Bedir, A. (2002). Türkiye'de Otomotiv Sanayii Gelişme Perspektifi. DPT, Ankara, Turkey, 2660, 1-44.

Bedir, A. (1999). Gelişmiş Otomotiv Sanayilerinde Ana-Yan Sanayiilişkileri ve Türkiye'de Otomotiv Yan Sanayinin Geleceği. DPT, Ankara, Turkey, 2495, 79-85.

Çakmak, Ö. (2017). Orta Asya: Bölgeselentegrasyongirişimlerive önerileri. Nisan, 17, 33-38.

Çiftçi, M., \& Seymen, R. (2011). Osmanlıendüstriyelüretimyapısının (1913-15) emeksermayebileşenindeincelenmesi. Uluslararası İnsan Bilimleri Dergisi, 8, 2-21.

Clingingsmith, D., \& Williamson, J. G. (2008). India's Deindustrialization in the 18th and 19th Centuries. Explorations in Economic History, 45, 209-234. https://doi.org/10.1016/j.eeh.2007.11.002

Çolak, M. (2003). XX. Yüzyıl Başlarında İstanbul'da Trafik ve Tramvay. Osmanlı 
Araștırmaları, Ístanbul, Turkey, 22, 177-185.

Ekrem, R. M. (1898). Araba Sevdası (pp. 209-237). İstanbul: İnkılap Kitapevi.

Emiroğlu, K. (2017). Gündelik Hayatımızın Tarihi. Dost Yayınları, Ankara, Turkey, 10, 443-445.

Engin, A. (1994). Devrimdireniyor. Cumhuriyet Gazetesi, Ağustos, 28, 12.

Fındıkoğlu, Z. F. (1940). Tanzimat'taÍçtimai Hayat (2nd ed., pp. 41-47). İstanbul: Maarif Maatbasi.

Karakışla, Y. S. (2002). 1914 Şoförlere ehliyet arabalara plaka. Toplumsal Tarih, İstanbul, Turkey, 107, 20-21.

Kerwin, K. (2003). One of Ford's Engines Is Humming (p. 26). New York: Business Week.

Koyuncu, T. (2015). İmzaotomobilfabrikasıengellendi. Hürriyet Gazetesi, Haziran, 05, 15.

Medina, C. A. (1969). Urbanisation, industrialisationet production alimentaire an Bresil (p. 3). Projection mesures des tendancesdemographiques, New York: Nation Unions.

Meyer, S. (1981). The Five Dollar Day: Labor Management and Social Control in the Ford Motor Company 1908-1921 (pp. 23-28). Albany, NY: State University of New York Press.

Muhit, O. E. (2012). Türk Otomotiv Sanayinin Tarihi Gelişimi. Journal of Pusula, 72, 3-4.

Odman, A. (2011). Galata Rihtımında Modern Zamanlar: Ford'un Tophane Montaj Fabrikası (pp. 106-121). 1925-1944 İstanbul Endüstri Mirasını Görünür Kılmak, İstanbul: Çekül Vakfı Yayınları.

Ökçün, A. G. (1997). Osmanlı Sanayi 1913, 1915 Yılları Sanayi İstatistiki (4th ed.). Ankara: SPK.

Okur, S. A., \& Serdaroğlu, A. (1994). The Role of the Small Scale Suppliers within the Dynamics of the Turkish Automotive Industry (pp. 56-58). Cambridge: Massachusetts Institute of Technology.

Önsoy, R. (1988). Tanzimat Dönemi Osmanlı Sanayi ve Sanayileşme Politikası. Türkiye Günlüğü, Türkiye İş Bankası Kültür Yayınları, Ankara, Turkey, 18, 18-22.

Pamuk, Ş. (2004). Urban Real Wages in Constantinople/Istanbul, 1100-2000. Global History of Prices and Wages Utrecht, 1, 19-21.

Pamuk, Ş. (2006). Estimating Economic Growth in the Middle East since 1820. The Journal of Economic History, 66, 3-6. https://doi.org/10.1017/S0022050706000337

Sağın, S. K. (1985). ÜlkeBaşarımı. Mühendislik ve Makinedergisi, 310, 22-32.

Sarc, Ö. C., (1940). Tanzimat ve Sanayimiz (pp. 423-440). Ankara: Maarif Vekaleti Neșriyatı.

Şener, S. (2007). Osmanlı Sanayileşmesüreci ve busüreçteözelsektörünrolü. Türk Dünyası Araştırmaları. Ankara, Turkey, 9, 56-89.

Taylor, A. (2003). Getting Ford in Gear (pp. 102-104). New York: Fortune.

Tonus, Ö. (2007). Gümrük Birliği Sonrasında Türkiye'de Dışa Açılılk ve Sanayileşme. D.Ü. Sosyal Bilimler Dergisi, 17, 193-214.

Topuz, G. (1993). Cumhuriyetin İlk Yıllarında (1923-30) Uygulanan Liberal Ekonomi Denemeleri ve Sonuçları. İ. Ü. AİITT Enstitüsü Yıllı̆̆g, 8, 265-270.

Türkmen, Z. (2003). Mahmut Şevket Paşa. DiyanetVakfi Íslam Ansiklopedisi. Ankara, Turkey, 27, 384-386.

Yaşar, O. (2013). Türkiye'de Otomotiv Ana ve Yan Sanayi ve Marmara Bölgesinde Kümelenme. Spring, 8, 779-805. 